\title{
Acetylcysteine in random skin flap in rats ${ }^{1}$
}

\section{Acetilcisteína em retalho cutâneo randômico em ratos}

\author{
Luiz Eduardo Felipe Abla², Heitor Carvalho Gomes², Sandro Percario², Lydia Masako Ferreira ${ }^{3}$
}

1. Plastic Surgery Division, Surgery Department, Federal University of São Paulo - UNIFESP

2. Assistant Professor, MD, PhD, Plastic Surgery Division - UNIFESP.

3. Head and Chairwoman Plastic Surgery Division, Post Graduate Program Coordinator, Plastic Surgery - UNIFESP.

\begin{abstract}
Purpose: Analyze the ability of Acetylcysteine to reduce distal necrosis in a random skin flap, in the rat. Methods: The present study utilized 28 adult male Wistar-EPM rats distributed, at random, in two groups of 14 animals. Control group rats (CG) received distilled water and Acetylcysteine group animals (NACG) received NAC (300 mg/kg) by oral infusion, 15 minutes before flap elevation. On the seventh postoperative day, percentage of distal necrosis was determined and skin samples collected in order to allow determination of MDA levels. Results: The mean necrotic area in CG group (control) was $66 \%$ and in NACG group (Acetylcysteine) $52 \%$, a statistically significant difference according to the Mann-Whitney test $(\mathrm{U}$ calc $=25$; $\mathrm{U}$ crit $=45)$. MDA levels were lower in the CG flap skin samples than in the NACG samples $(\mathrm{U}$ calc $=24$; $\mathrm{U}$ crit $=45)$, the oposite being true in the normal skin samples $(\mathrm{U}$ calc $=10$; $U$ crit $=45)$. Conclusion: Acetylcysteine was effective, according to the model used, reducing the percentage of distal necrosis in NACG rats.
\end{abstract}

Key words: Surgical Flaps. Lipid peroxidation. Acetylcysteine. Rats.

\section{RESUMO}

Objetivo: Analisar a capacidade da Acetilcisteína em reduzir a necrose distal em um retalho cutâneo randômico, no rato. Método: O presente trabalho utilizou 28 ratos machos adultos Wistar-EPM divididos, ao acaso, em dois grupos de 14 animais. Os ratos do grupo controle (CG) receberam água destilada e os animais do grupo Acetilcisteína (NACG) receberam NAC (300 mg/kg) por infusão oral, 15 minutos antes da elevação do retalho. No sétimo dia de pós-operatório, a porcentagem de necrose distal foi determinada e amostras de pele colhidas para permitir a determinação dos níveis de MDA. Resultados: A área média de necrose no grupo CG (controle) foi 66 \% e no grupo NACG (Acetilcisteína) 52 \%, uma diferença estatisticamente significante de acordo com o teste de Mann-Whitney (U calc = 25; U crit = 45). Os níveis de MDA foram menores nas amostras de pele do retalho no grupo CG do que nas amostras do grupo NACG (U calc $=24$; $U$ crit $=45$ ), o oposto sendo verdadeiro nas amostras de pele normal ( $U$ calc $=10$; U crit $=45)$. Conclusão: A Acetilcisteína foi eficaz, de acordo com o modelo usado, reduzindo a porcentagem de necrose distal nos ratos NACG.

Descritores: Retalhos Cirúrgicos. Peroxidação de Lipídeos. Acetilcisteína. Ratos.

\section{Introduction}

The risk of skin slough after elevation of a random flap is a matter of preocupation in Plastic Surgery ${ }^{1,2}$. Experimental works foccusing on the reduction of skin necrosis have been done and the benefic role of antioxidant drugs discussed $^{3,4}$. Acetylcysteine, a well known antioxidant substance, had been used before with favorable results ${ }^{3,5}$. Therefore, the role of Acetylcysteine in the protection of random skin flaps in rats was studied.

\section{Methods}

Twenty-eight adult male Wistar-EPM rats were divided, at random, into two groups of 14 animals. Animals in the control group (CG) received distilled water and rats in group NACG received Acetylcysteine $(300 \mathrm{mg} / \mathrm{kg}$ ) by oral infusion, 15 minutes before flap elevation. Pentobarbital (40 mg/kg) was used intraperitoneally to provide anesthesia. After that, the rats were shaved and a cranially based random pattern skin flap was elevated $(10 \times 4 \mathrm{~cm})$ on the back of the animals ${ }^{6}$. A plastic barrier was then interposed between the flap and its bed ${ }^{7}$. The wound was closed with simple nylon 4-0 stitches .

On the seventh postoperative day, necrosis on the distal portion of the flaps was estimated by means of the paper template method ${ }^{8}$ Skin samples were obtained to permit analyzis of malondyaldehyde (MDA) levels ${ }^{9}$. One sample was collected from the transition area between viable and necrotic tissue and the other, distant from the flap, from a normal skin area.

\section{Results}

Necrotic area in CG group (control) ranged between 51 $\%$ and $77 \%$ (average $66 \%$ ), while that in NACG group 
(Acetylcysteine) ranged between $38 \%$ and $70 \%$ (average $52 \%$ ). MDA concentrations in normal skin samples ranged between 1255 and 3345 ng/ml (average 2038 ng/ml) in CG and between 177 and $1889 \mathrm{ng} / \mathrm{ml}$ (average $935 \mathrm{ng} / \mathrm{ml}$ ) in NACG. MDA levels in the viable to necrotic transiton skin samples ranged between 417 and $1915 \mathrm{ng} / \mathrm{ml}$ (average 1235 $\mathrm{ng} / \mathrm{ml}$ ) in CG and between 1051 and $4465 \mathrm{ng} / \mathrm{ml}$ (average 2346 $\mathrm{ng} / \mathrm{ml}$ ) in NACG. Mann-Whitney test for independent groups showed statistically significant differences (Tables 1-3).

TABLE 1 - Percentage of necrotic area on the seventh postoperative day. Mann-Whitney test (statistically significant)

\begin{tabular}{cll}
\hline Animal & CG & NACG \\
\hline 1 & 66 & 70 \\
2 & 51 & 57 \\
3 & 63 & 45 \\
4 & 77 & 62 \\
5 & 67 & $*$ \\
6 & 68 & 55 \\
7 & 67 & 60 \\
8 & 71 & 42 \\
9 & 59 & 44 \\
10 & 51 & 42 \\
11 & 75 & 60 \\
12 & 59 & 38 \\
13 & 72 & 45 \\
14 & 72 & $*$ \\
Average & $\mathbf{6 6}$ & $\mathbf{5 2}$ \\
\hline
\end{tabular}

* two rats died in the postoperative period.

TABLE 2 - Concentration of malondyaldehyde (ng/ml) from the normal skin samples on the seventh postoperative day.

\begin{tabular}{ccc}
\hline Animal & CG & NACG \\
\hline 1 & 2049 & 1889 \\
2 & 2012 & 874 \\
3 & 1458 & 862 \\
4 & 1255 & 1287 \\
5 & 3345 & $*$ \\
6 & 2393 & 1169 \\
7 & 1784 & 1417 \\
8 & 2116 & 519 \\
9 & 1612 & 578 \\
10 & 2329 & 354 \\
11 & 2332 & 1582 \\
12 & 2339 & 177 \\
13 & 1614 & 519 \\
14 & 1885 & $*$ \\
Average & $\mathbf{2 0 3 8}$ & $\mathbf{9 3 5}$ \\
\hline
\end{tabular}

Mann-Whitney test (statistically significant)

* two rats died in the postoperative period.
TABLE 3 - Concentration of malondyaldehyde (ng/ml) from the viable to necrotic transition skin samples on the seventh postoperative day.

\begin{tabular}{ccc}
\hline Animal & CG & NACG \\
\hline 1 & 1683 & 4465 \\
2 & 786 & 2456 \\
3 & 884 & 1944 \\
4 & 759 & 4240 \\
5 & 1683 & $*$ \\
6 & 1915 & 1523 \\
7 & 1477 & 3201 \\
8 & 697 & 1700 \\
9 & 417 & 1850 \\
10 & 1005 & 1252 \\
11 & 1299 & 2657 \\
12 & 1661 & 1051 \\
13 & 1545 & 1815 \\
14 & 1485 & $*$ \\
Average & $\mathbf{1 2 3 5}$ & $\mathbf{2 3 4 6}$ \\
Mann-Whitney test (statistically significant) \\
* two rats died in the postoperative period.
\end{tabular}

\section{Discussion}

Random pattern skin flaps represent valuable and common procedures in Plastic Surgery. Nevertheless, the risk of ischemia and necrosis is allways present, justifying the need of research for protective measures. Free radicals produce deleterious effects on skin flaps and continue to be intensivelly studied. Recent works have foccused on the antioxidant drugs.

Acetylcysteine (NAC) is a very well known antioxidant compound, used extensivelly in Pneumology. Easily obtainable and manipulated, it has low toxicity and the advantage of oral administration ${ }^{3,5}$. The dosis herein utilized (300 mg/kg/day) was two times higher than that previously presented $^{3}$ and was chosen in view of the low toxicity of this drug. It must be stressed that this is a high dose, not readily applicable to human beings, but considered necessary in order to promote adequate antioxidant effect in this experimental model.

The herein revisited McFarlane-like skin flap represents a practical experimental tool to study distal necrosis. The plastic barrier interposed between the flap and the donor bed (a latter contribution), prevents flap revascularization through the bed vessels. The percentage of necrosis was determined via the paper template method, another very usefull procedure.

In CG group (control) rats, the average percentage of necrosis was $66 \%$; in NACG group (Acetylcysteine) it was $52 \%$. Acetylcysteine was effective, according to the model used, reducing the percentage of distal necrosis on the flap in NACG animals in relation to CG rats.

The antioxidant role of Acetylcysteine was studied through the determination of MDA levels in skin samples. MDA was measured from two skin samples of each animal from both groups, using normal and viable to necrotic transition skin. 
In order to allow proper study of the antioxidant action of Acetylcysteine, this animal model had to promote both ischemia and necrosis in the flaps, with consequent lipid peroxidation and liberation of its products and byproducts. Normal skin samples in CG group (control) revealed an average MDA level of $2038 \mathrm{ng} / \mathrm{ml}$, as opposed to NACG group (Acetylcysteine), with $935 \mathrm{ng} / \mathrm{ml}$, corroborating the antioxidant action of this substance.

Notwithstanding, MDA values obtained from samples of skin from the viable to necrotic transition area were lower in CG(1235 ng/ml) than in NACG (2346 ng/ml), an unexpected finding, but previously presented ${ }^{10}$. In that occasion, the author stated that high MDA levels do not necessarily lead to cellular death, provided that the proteic thiols remain unharmed.

The present study contributed to the understanding of the oxidative processes that occur after elevation of a random skin flap, as well as the benefic role of the antioxidants.

\section{References}

1. Rees TD, Liverett DM, Guy CL. The effect of cigarette smoking on skin-flap survival in the face lift patient. Plast Reconstr Surg. 1984; 73: 911-5.

2. Riefkohl R, Wolfe JA, Cox EB, McCarty KS. Association between cutaneous occlusive vascular disease, cigarette smoking, and skin slough after rhytidectomy. Plast
Reconstr Surg. 1986; 77: 592-5.

3. Gomes HC, Bueno PCS, Scardoeli CAC, Percario S, Landman MRL, Ferreira LM. Effect of Acetylcysteine in a random skin flap after administration of nicotine, in the rat. Folha Med. 1998; 117: 209-11.

4. Duarte IS, Gomes HC, Ferreira LM. Effect of Dimethyl sulphoxide on necrosis of skin flaps in rats. Can J Plast Surg. 1998; 6: 93-7.

5. Bernard GR, Luch WD, Niedermeyer ME, Snapper JR, Ogletree ML, Brigham KL. Effect of Acetylcysteine on the pulmonary response to endotoxin in the awake sheep and upon in vitro granulocyte function. J Clin Ivest. 1984; 76: $1776-84$.

6. McFarlane RM, DeYoung G, Henry RA. The design of a pedicle flap in the rat to study necrosis and its prevention. Plast Reconstr Surg. 1965; 35: 245-8.

7. Ugland O. Flaps and flaps necrosis. Acta Chir Scand. 1966; 131: 408-12.

8. Sasaki GH, Pang Y. Hemodynamics and viability of acute neurovascular island skin flaps in rats. Plast Reconstr Surg. 1980; 65: 152-8.

9. Percario S, Vital ACC, Jablonka F. Dosagem do Malondialdeido. Newslab. 1994; 6: 46-50.

10. Bhatnagar A. Biochemical mechanism of cell injury caused by free radical-initiated reactions. Moll Cell Biochem. 1994; 137: 9-16.
Correspondence:

Luiz Eduardo Felipe Abla MD, PhD

Rua Napoleão de Barros, 715, $4^{\circ}$ andar

São Paulo, SP - BRASIL - 04024-900

Tel:(11) 5576-4118 Fax:(11) 5571-6579 Cel:(11) 9971-2443

E-mail: sandra.dcir@epm.br|labla@uol.com.br
Conflict of interest: none Financial source: none

Received: 10/6/2004

Revised: $11 / 28 / 2004$

Aproved: 12/29/2004

\section{How to cite this article:}

Abla LEF, Gomes HC, Percario S, Ferreira LM. Acetylcysteine in random skin flap in rats. Acta Cir Bras. [serial online] 2005 Mar-Apr;20(2). Available from URL: http://www.scielo.br/acb 